\title{
Mercury Reduction by Nanoparticulate Vivianite
}

\author{
Marjorie Etique, Sylvain Bouchet,* James M. Byrne, Laurel K. ThomasArrigo, Ralf Kaegi, \\ and Ruben Kretzschmar
}

Cite This: Environ. Sci. Technol. 2021, 55, 3399-3407

Read Online

ABSTRACT: Mercury $(\mathrm{Hg})$ is a toxic trace element of global environmental concern which has been increasingly dispersed into the environment since the industrial revolution. In aquatic and terrestrial systems, $\mathrm{Hg}$ can be reduced to elemental $\mathrm{Hg}\left(\mathrm{Hg}^{0}\right)$ and escape to the atmosphere or converted to methylmercury $(\mathrm{MeHg})$, a potent neurotoxin that accumulates in food webs. $\mathrm{Fe}^{\mathrm{II}}$-bearing minerals such as magnetite, green rusts, siderite, and mackinawite are recognized $\mathrm{Hg}^{\mathrm{II}}$ reducers. Another potentially $\mathrm{Hg}$-reducing mineral, which commonly occurs in Fe- and organic/P-rich sediments and soils, is the ferrous iron phosphate mineral vivianite $\left(\mathrm{Fe}_{3}{ }_{3}\left(\mathrm{PO}_{4}\right)_{2} \cdot 8 \mathrm{H}_{2} \mathrm{O}\right)$, but its reaction with $\mathrm{Hg}^{\mathrm{II}}$ has not been studied to date. Here, nanoparticulate vivianite (particle size $\sim 50$

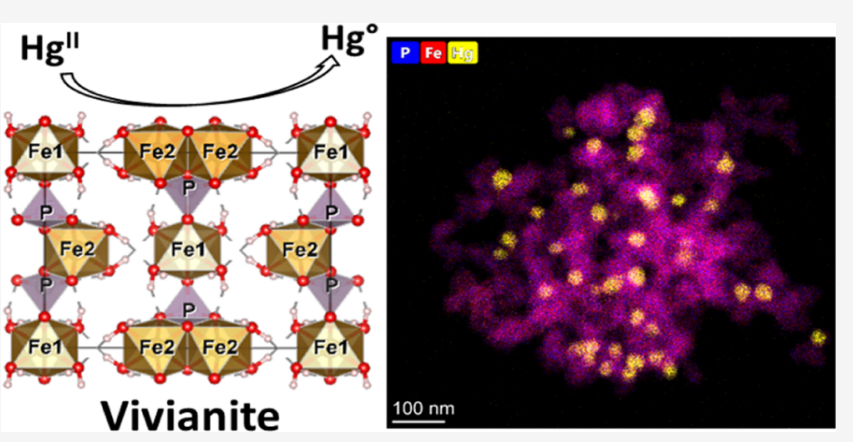
$\mathrm{nm} ; \mathrm{Fe}^{\mathrm{II}}$ content $>98 \%$ ) was chemically synthesized and characterized by a combination of chemical, spectroscopic, and microscopic analyses. Its ability to reduce $\mathrm{Hg}^{\mathrm{II}}$ was investigated at circumneutral $\mathrm{pH}$ under anoxic conditions over a range of $\mathrm{Fe}^{\mathrm{II}} / \mathrm{Hg}^{\mathrm{II}} \mathrm{ratios}$ $(0.1-1000)$. For $\mathrm{Fe}^{\mathrm{II}} / \mathrm{Hg}^{\mathrm{II}}$ ratios $\geq 1$, which are representative of natural environments, $\mathrm{Hg}^{\mathrm{II}}$ was very quickly and efficiently reduced to $\mathrm{Hg}^{0}$. The ability of vivianite to reduce $\mathrm{Hg}^{\mathrm{II}}$ was found to be similar to those of carbonate green rust and siderite, two of the most effective $\mathrm{Hg}$-reducing minerals. Our results suggest that vivianite may be involved in abiotic $\mathrm{Hg}^{\mathrm{II}}$ reduction in Fe and organic/P-rich soils and sediments, potentially contributing to $\mathrm{Hg}$ evasion while also limiting $\mathrm{MeHg}$ formation in these ecosystems.

\section{INTRODUCTION}

Mercury $(\mathrm{Hg})$ is a trace element that is released into the environment from natural processes (e.g., volcanic emissions) and anthropogenic sources (e.g., coal burning). ${ }^{1}$ Since the beginning of the industrial revolution, concentrations of $\mathrm{Hg}$ have increased in all environmental compartments, including soils, sediments, water, atmosphere, and biota. ${ }^{2} \mathrm{Hg}$ can be present in different species and oxidation states in the environment. ${ }^{3} \mathrm{Hg}^{0}$ (metallic, elemental $\mathrm{Hg}$ ) is the most abundant species in the atmosphere, allowing its long-range transport, while $\mathrm{Hg}^{\mathrm{II}}$ (mercuric $\mathrm{Hg}$ ) is the predominant oxidation state in many aquatic and terrestrial systems. Because of the lipophilicity and protein-binding properties of monomethylmercury ( $\mathrm{MeHg}$ ), $\mathrm{Hg}$ builds up to high levels along aquatic and terrestrial food webs, ${ }^{4,5}$ thereby causing severe health effects in wildlife and humans. ${ }^{6}$ Identifying new mechanisms involved in the transformations of $\mathrm{Hg}$ is key for a better understanding of its fate, to mitigate its toxic effects, and develop remediation techniques.

Reduction of $\mathrm{Hg}^{\mathrm{II}}$ to $\mathrm{Hg}^{0}$ is an important pathway controlling its evasion from aquatic and terrestrial ecosystems, ${ }^{1,7}$ and thus, its redistribution through the atmosphere while $\mathrm{Hg}$ would otherwise be buried and escape surficial cycling. In photic compartments, the reaction is mostly photochemically driven, ${ }^{8}$ while in the absence of light, it can proceed through either biotic and abiotic pathways. ' Some bacteria are specifically equipped with genes conferring resistance against $\mathrm{Hg}$ but the $\mathrm{Hg}$ concentration threshold to activate these genes suggests that their activities are restricted to highly contaminated sites. ${ }^{10}$ Several dissimilatory metalreducing bacteria are also able to reduce low concentrations of $\mathrm{Hg}$ in relation with the activity of respiratory electron transport chains ${ }^{11}$ but under realistic environmental conditions, the reaction is probably prevented by $\mathrm{Hg}$ sorption onto cell surfaces by thiol groups. ${ }^{12} \mathrm{Hg}$ can also be reduced abiotically by organic matter $(\mathrm{OM})^{13}$ but at environmental $\mathrm{OM}$ and $\mathrm{Hg}$ concentrations, the reaction is also likely outcompeted by the strong complexation of thiol groups. ${ }^{14}$ On the other hand, $\mathrm{Fe}^{\mathrm{II}}$ bearing minerals, such as phlogopite, ${ }^{15}$ magnetite, ${ }^{16}$ green rusts, ${ }^{19,18}$ mackinawite, ${ }^{19}$ and siderite ${ }^{20}$ are well known to be efficient $\mathrm{Hg}^{\mathrm{II}}$ reducers. The reduction reaction proceeds in two steps with $\mathrm{Hg}$ complexation at the mineral surface required prior to electron transfer from $\mathrm{Fe}^{\mathrm{II}}$. The reaction yields and kinetics are controlled by several factors, including the mineral specific surface area (SSA), ${ }^{16,20} \mathrm{Fe}^{\mathrm{II}}$ concentration, ${ }^{21}$ and

Received: August 3, 2020

Revised: January 15, 2021

Accepted: January 22, 2021

Published: February 8, 2021 
surface charge determined by its point of zero charge and solution $\mathrm{pH}^{18}$ but also by the presence of organic and inorganic ligands that will affect the dissolved $\mathrm{Hg}$ speciation and act as competitors for the mineral surface sites. ${ }^{16,18,21,22}$

Vivianite $\left(\mathrm{Fe}_{3}{ }_{3}\left(\mathrm{PO}_{4}\right)_{2} \cdot 8 \mathrm{H}_{2} \mathrm{O}\right)$, the most common stable iron phosphate mineral, has been reported to occur worldwide in a large variety of natural aquatic and terrestrial environments, such as freshwater or coastal sediments and sinking particles, bogs, waterlogged and organic-rich soils, but also in anthropogenic systems such as sewage sludges (see Rothe et al., ${ }^{23}$ for a comprehensive review on the topic). Its formation occurs in oligotrophic as well as in eutrophic ecosystems where the production of sulfides is limited relative to the $\mathrm{Fe}$ present. $^{24}$ It appears to be favored under organic-rich conditions where readily degradable organic debris enable the development of reducing microenvironments, promoting $\mathrm{Fe}$ reduction, and thus, the release of $\mathrm{Fe}^{\mathrm{II}}$ and orthophosphates previously sequestered by $\mathrm{Fe}$ oxyhydroxides. Although the quantitative importance of vivianite remains difficult to establish, it is one of the most important sinks of phosphorus in reducing natural environments, which could represent up to $40-50 \%$ of total $\mathrm{P}$ in sulfide-poor environments. ${ }^{25-27}$ It has also been found to be the dominant $\mathrm{Fe}$ phase in the deep anoxic waters and sediments of the ferruginous and low-sulfate Lake Pavin. ${ }^{28}$ The reactivity of vivianite toward trace elements, and especially, its ability to immobilize and/or reduce them, has already been established for several important metal(loids) including, for example, $\mathrm{As},{ }^{29,30} \mathrm{U},{ }^{31} \mathrm{Zn},{ }^{32} \mathrm{Cu},{ }^{33} \mathrm{Ni}$, and $\mathrm{Co}^{34}$ or $\mathrm{Cr}^{35}$ However, the reactivity of vivianite toward $\mathrm{Hg}^{\mathrm{II}}$ has not yet been studied, and we hypothesize that it may contribute to the reduction of $\mathrm{Hg}^{\mathrm{II}}$ in organic/P-rich soils and sediments, where $\mathrm{Hg}$ also accumulates thus promoting its evasion and redistribution while also limiting its methylation.

In this work, vivianite was abiotically synthesized by precipitation and characterized by a combination of complementary techniques: X-ray diffraction (XRD), Mössbauer spectroscopy, X-ray absorption spectroscopy (XAS, Fe Kedge), and transmission electron microscopy (TEM). Nanoparticles of pure vivianite were obtained and the main objective of this work was to demonstrate their ability to reduce $\mathrm{Hg}^{\mathrm{II}}$ to $\mathrm{Hg}^{0}$ and determine the reaction yields and kinetics at various $\mathrm{Fe}^{\mathrm{II}} / \mathrm{Hg}^{\mathrm{II}}$ ratios $(0.1,1,100$, and 1000$)$ at circumneutral $\mathrm{pH}$ under anoxic conditions. The mass balance between $\mathrm{Hg}^{\mathrm{II}}$ reduction, $\mathrm{Hg}^{0}$ production, and $\mathrm{Fe}^{\mathrm{II}}$ oxidation was determined for the $\mathrm{Fe}^{\mathrm{II}} / \mathrm{Hg}^{\mathrm{II}}$ ratio 1 , as well as the change in mineralogy of the $\mathrm{Hg}^{\mathrm{II}}$-reacted vivianite. The kinetic parameters of the reduction reaction were determined for all ratios and compared to the other $\mathrm{Fe}^{\mathrm{II}}$-bearing minerals.

\section{MATERIALS AND METHODS}

All solutions were prepared from analytical grade chemicals with boiled, $\mathrm{N}_{2}$-outgassed doubly deionized (DDI) water (Milli-Q, Millipore, 18.2 M $\Omega \mathrm{cm}$ ). Brown glass vials used for $\mathrm{Hg}$ reduction experiments were washed successively with $10 \%$ nitric acid $\left(\mathrm{HNO}_{3}, \mathrm{v} / \mathrm{v}\right)$ and $10 \%$ hydrochloric acid $(\mathrm{HCl}, \mathrm{v} /$ $\mathrm{v}$ ), and finally rinsed with anoxic DDI water. Teflon caps were washed in the same way but with $1 \%$ acids $(\mathrm{v} / \mathrm{v})$.

2.1. Vivianite Synthesis. Vivianite was synthesized in an anoxic chamber (MBraun, UNIlab Plus, $\mathrm{N}_{2}$ atmosphere, $<1$ ppm $\left.(\mathrm{v} / \mathrm{v}) \mathrm{O}_{2}\right)$, at $45{ }^{\circ} \mathrm{C}$ by precipitation from $1 \mathrm{mmol} \mathrm{L}^{-1}$ solutions of $\left(\mathrm{NH}_{4}\right)_{2} \mathrm{HPO}_{4}$ and $\mathrm{Fe}^{\mathrm{II}} \mathrm{SO}_{4} \cdot 7 \mathrm{H}_{2} \mathrm{O}$ mixed in appropriate proportions ${ }^{36}$ (i.e. a slight excess of $\mathrm{P}$ to scavenge all $\mathrm{Fe}^{2+}$ species) to have final concentrations of $\mathrm{Fe}^{\mathrm{II}}$ ranging from $50 \mathrm{nmol} \mathrm{L} \mathrm{L}^{-1}$ to $50 \mu \mathrm{mol} \mathrm{L} \mathrm{L}^{-1}$. At this stage, $\mathrm{pH}$ was slightly acidic and readjusted to $7.0 \pm 0.2$ with the dropwise addition of a $4 \mathrm{M} \mathrm{NaOH}$ solution. A white precipitate (Figure S1) appeared immediately and was continuously stirred at 400 $\mathrm{rpm}$ for $1 \mathrm{~h}$ to entirely consume free $\mathrm{Fe}^{\mathrm{II}}$ species. Because vivianite is sensitive to light exposure (Figure S1c), its synthesis was conducted in amber glass flasks.

2.2. $\mathrm{Hg}^{\mathrm{II}}$ Reduction Kinetic Experiments. A first set of experiments was carried out outside the anoxic chamber with a purge and trap setup (Figure S2) to precisely determine the $\mathrm{Hg}$ mass balance with respect to $\mathrm{Hg}^{0}$ production and the reaction stoichiometry with respect to Fe oxidation. Briefly, the purge and trap setup was assembled in the anoxic chamber, sealed, removed, and then the brown glass reactor containing vivianite (final concentration of $8.4 \mathrm{mg} \mathrm{L}^{-1}$ ) was spiked with a $\mathrm{Hg}^{\mathrm{II}} \mathrm{SO}_{4}$ solution (final concentration of $50 \mu \mathrm{mol} \mathrm{L}{ }^{-1}$ ), that is, an $\mathrm{Fe}^{\mathrm{II}} / \mathrm{Hg}^{\mathrm{II}}$ ratio of 1 (Table $\left.\mathrm{S} 1\right)$. Elemental mercury $\left(\mathrm{Hg}^{0}\right)$ produced during these $\mathrm{Hg}^{\mathrm{II}}$ reduction experiments was stripped off from the vivianite solutions by a constant stream of ultrapure $\mathrm{N}_{2}$ gas (4.5 quality $\mathrm{N}_{2}, 200 \mathrm{~cm}^{3} \mathrm{~min}^{-1}$ transiting through PTFE tubing) and trapped in a $0.6 \% \mathrm{w} / \mathrm{v} \mathrm{KMnO}_{4}$ solution acidified by $10 \% \mathrm{v} / \mathrm{v} \mathrm{HCl}$. Both the initial vivianite solution to which $\mathrm{Hg}^{2+}$ was added and the $\mathrm{KMnO}_{4}$ solutions were analyzed for $\mathrm{Hg}$ by gas chromatography-inductively coupled plasma-mass spectrometry (GC-ICP-MS) (see below).

To study the kinetics of $\mathrm{Hg}^{\mathrm{II}}$ reduction by vivianite, experiments were carried out in the anoxic chamber at four $\mathrm{Fe}^{\mathrm{II}} / \mathrm{Hg}^{\mathrm{II}}$ ratios, that is, $0.1,1,100$, and 1000 (Table S1); the $\mathrm{Hg}^{\mathrm{II}}$ solution was prepared from a $\mathrm{HgSO}_{4}$ salt (Merck, 99\%) in $0.5 \mathrm{M} \mathrm{HCl}$, then its $\mathrm{pH}$ was adjusted to $7.0 \pm 0.2$ with $1 \mathrm{M}$ $\mathrm{NaOH}$ just before its addition to $200 \mathrm{~mL}$ vivianite suspensions (contained in $250 \mathrm{~mL}$ bottles leaving a headspace volume larger than $50 \mathrm{~mL}$ ) to reach a final concentration of $0.5 \mu \mathrm{mol}$ $\mathrm{L}^{-1} \mathrm{Hg}$. The suspensions were continuously magnetically stirred at $400 \mathrm{rpm}$ to allow for the produced $\mathrm{Hg}^{0}$ to escape into the headspace volume. A small volume $(0.5 \mathrm{~mL})$ of the unfiltered $\mathrm{Hg}^{\mathrm{II}}$-reacted suspension (i.e., with dissolved and adsorbed $\mathrm{Hg}$ ) was regularly sampled over $24 \mathrm{~h}$ and immediately dissolved in $6 \mathrm{M} \mathrm{HCl}$ to stop the reaction by dissolving the mineral phase and stabilize Hg. Control experiments were performed under the exact same conditions except that vivianite was replaced by aqueous $\mathrm{Fe}^{2+}(50 \mu \mathrm{mol}$ $\mathrm{L}^{-1}, \mathrm{pH}$ 6.5) or deoxygenated water to assess the reactivity of $\mathrm{Hg}^{\mathrm{II}}$ species toward free $\mathrm{Fe}^{2+}$ aq versus structural $\mathrm{Fe}^{\mathrm{II}}$ in vivianite, and the potential losses of $\mathrm{Hg}^{\mathrm{II}}$.

2.3. Chemical Analyses: $\mathrm{pH}$ Monitoring and $\mathrm{Fe}$ and $\mathrm{Hg}$ Speciation. The initial $\mathrm{pH}$ value of vivianite suspensions before $\mathrm{Hg}^{\mathrm{II}}$ spike was measured using a microelectrode immersed in $1 \mathrm{~mL}$ of the sample maintained in an anoxic chamber. A data-reading time of $30 \mathrm{~s}$ was used to obtain stable values. Total $\mathrm{Fe}^{\mathrm{II}}$ and total $\mathrm{Fe}\left(\mathrm{Fe}_{\mathrm{TOT}}=\mathrm{Fe}^{\mathrm{II}}+\mathrm{Fe}^{\mathrm{III}}\right)$ in the suspensions (i.e., solids + solution) were determined using the ferrozine method. ${ }^{37}$ At regular time intervals, the suspensions were sampled using syringes and part of the samples were dissolved in $2 \mathrm{M} \mathrm{HCl}$ for $15 \mathrm{~min}$, and then diluted with DDI water. $\mathrm{Fe}^{\mathrm{II}}$ species were measured immediately after adding the ferrozine by UV absorption at $562 \mathrm{~nm}$ (Cary $60 \mathrm{UV}$-vis, Agilent). $\mathrm{Fe}_{\mathrm{TO}}$ species were evaluated at the same wavelength after reduction with $1.4 \mathrm{M} \mathrm{NH}_{2} \mathrm{OH}$ and $\mathrm{HCl}$ for $10 \mathrm{~min}$ in darkness and stabilization of $\mathrm{pH}$ by the addition of $10 \mathrm{M}$ $\mathrm{CH}_{3} \mathrm{CO}_{2} \mathrm{NH}_{4}$. 
The concentrations of $\mathrm{Hg}^{\mathrm{II}}$ were determined by $\mathrm{GC}-\mathrm{ICP}-$ MS (Agilent 8800 ICP-QQQ-MS and 7890B GC fitted with an Agilent J\&W HP-5 column, $30 \mathrm{~m}$ long, $0.320 \mathrm{~mm}$ I.D., 0.25 $\mu \mathrm{m}$ film thickness) according to Monperrus et al. ${ }^{38}$ but using external calibration. Briefly, aliquots of the samples dissolved in $6 \mathrm{M} \mathrm{HCl}$ were added to $0.5 \mathrm{M}$ sodium acetate buffer and the $\mathrm{pH}$ was adjusted to $\mathrm{pH} 4$ with a $\mathrm{NH}_{3}$ solution if necessary. Proper volumes of isooctane and $5 \%(\mathrm{w} / \mathrm{v})$ sodium tetrapropylborate were then added, and the vials were placed on an orbital shaker for $10 \mathrm{~min}$. After the derivatization reaction was complete, the organic phase was transferred to $\mathrm{GC}$ vials and injected into the $\mathrm{GC}-\mathrm{ICP}-\mathrm{MS}$ using an autosampler.

2.4. Fe-Bearing Mineral Characterization. 2.4.1. X-ray Diffraction. XRD data for unreacted and $\mathrm{Hg}^{\mathrm{II}}$-reacted vivianites were collected with a Bruker D8 ADVANCE diffractometer equipped with a high-resolution energydispersive one-dimensional (1-D) detector (LYNXEYE). The $\mathrm{X}$-ray source was a $\mathrm{Cu}$ anode $\left(k_{\alpha 1}=1.5406 \AA \mathrm{i}_{\alpha 2}=1.5444 \AA\right)$. The diffractograms were recorded in the Bragg-Brentano geometry in the $10^{\circ}-70^{\circ} 2 \theta$ range with a $0.02^{\circ}$ step size and an acquisition time of $4 \mathrm{~s}$ per step in the dark. In order to perform XRD analyses under inert atmosphere conditions $\left(\mathrm{N}_{2}\right.$ atmosphere), unreacted and $\mathrm{Hg}^{\mathrm{II}}$-reacted vivianites were centrifuged $\left(10,000 \mathrm{~g}\right.$ at $22{ }^{\circ} \mathrm{C}$ for $\left.10 \mathrm{~min}\right)$, concentrated, and washed three times with $\mathrm{O}_{2}$-free DDI water before being deposited onto polished silicon wafer (Sil'tronix Silicon Technologies, France) to form a homogeneous film after a $24 \mathrm{~h}$ drying period in an anoxic chamber protected against light oxidation by $\mathrm{Al}$ foil. A plexiglas dome equipped with an anti-scatter knife edge (Bruker, A100B138-B141) was used to seal the dried film and allow anoxic conditions to be maintained during the XRD analysis. The diffractograms were analyzed by Rietveld fitting in TOPAS (V.5.0; Bruker, Germany) based on CIF files for vivianite (American Mineralogist Crystal Structure Database, \#0015722) and metavivianite (International Crystal Structure Database, $\# 188922$ ), respectively.

2.4.2. Transmission Electron Microscopy. TEM was conducted using a dedicated scanning transmission electron microscope (STEM, HD2700Cs, Hitachi, Japan) equipped with a high-angle annular dark field (HAADF) detector to visualize contrasts in atomic weights, and a secondary electron detector to image the morphology of the particles. Elemental analyses, including elemental distributions, were conducted on a (S)TEM (Talos F200X, Thermo Fisher) coupled to an energy-dispersive X-ray (EDX) system (Super-X EDX, 4 detector configurations, FEI), also equipped with a HAADF detector. Both microscopes were operated at an acceleration voltage of $200 \mathrm{kV}$. Carbon-coated $\mathrm{Cu}$ grids were functionalized with $0.1 \%$ poly-L-lysine solution for $10-15 \mathrm{~min}$ and washed with DDI water before centrifuging unreacted and $\mathrm{Hg}^{\mathrm{II}}$-reacted vivianite suspensions at $14,000 \mathrm{~g}$ for $1 \mathrm{~h}$ on TEM grids. Afterward, TEM grids were rinsed three times with DDI water to prevent the formation of precipitates from dissolved salts. The characterization of the particle morphology and size were determined from 300 individual particles using ImageJ software. The SSA $\left(\mathrm{m}^{2} \mathrm{~g}^{-1}\right)$ was calculated for each individual vivianite particle based on their respective diameter, assuming that particles are spherical, according to eq $1^{39}$

$$
\operatorname{SSA}=6000 /(\rho \times d)
$$

where $d(\mathrm{~nm})$ is the diameter and $\rho\left(\mathrm{g} \mathrm{cm}^{-3}\right)$ is the density (2.69 $\mathrm{g} \mathrm{cm}^{-3}$ for vivianite).

2.4.3. ${ }^{57} \mathrm{Fe}$ Mössbauer Spectroscopy. ${ }^{57} \mathrm{Fe}$ Mössbauer spectroscopy was used to quantitatively characterize unreacted and $\mathrm{Hg}^{\mathrm{II}}$-reacted vivianites. Dried powder of unreacted vivianite $(\sim 50 \mathrm{mg})$ was collected after centrifugation $\left(10,000 \mathrm{~g}\right.$ at $22{ }^{\circ} \mathrm{C}$ for $\left.10 \mathrm{~min}\right)$, rinsed three times with anoxic DDI water, and filtered in an anoxic chamber. Then, the dried unreacted vivianite was loaded onto a Plexiglas holder $\left(1 \mathrm{~cm}^{2}\right)$. The wet filtered $\mathrm{Hg}^{\mathrm{II}}$-reacted sample was prepared by passing liquid material through a $0.44 \mu \mathrm{m}$ filter, which was then sealed between two layers of Kapton tape. The sample sandwich was kept in a freezer $\left(-20{ }^{\circ} \mathrm{C}\right)$ under anoxic conditions until measurement. All samples were sealed in Schott bottles and only exposed to air immediately prior to loading inside a closed-cycle exchange gas ( $\mathrm{He})$ cryostat (Janis cryogenics). Measurements were collected at $77 \mathrm{~K}$ with a constant acceleration drive system (WissEL) in transmission mode with a ${ }^{57} \mathrm{Co} / \mathrm{Rh}$ source and calibrated against $7 \mu \mathrm{m}$ thick $\alpha_{-}{ }^{57} \mathrm{Fe}$ foil measured at room temperature. All spectra were analyzed using Recoil (University of Ottawa) by applying a Voight Based Fitting routine. The half width at half maximum was fixed to a value of $0.130 \mathrm{~mm} / \mathrm{s}$ for all samples.

2.4.4. Bulk Fe XAS Analyses. Unreacted vivianite was analyzed by bulk Fe K-edge $(7112 \mathrm{eV})$ extended X-ray absorption fine structure (EXAFS) spectroscopy at the SAMBA beamline (SOLEIL Synchrotron, St. Aubin, France). For this analysis, the dried sample material was pressed into 1.3 $\mathrm{cm}$ pellets and sealed with Kapton tape. To prevent changes in the Fe oxidation state, samples for XAS analyses were prepared in an anoxic glovebox, where they were doubly sealed in $\mathrm{Al}$ foil for transport to the synchrotron to be measured under anoxic conditions. To this end, immediately prior to sample mounting, Al-sealed bags were opened in ambient air and the Kapton-sealed pellet was mounted onto the sample holder which was immediately plunged into liquid $\mathrm{N}_{2}$. The $\mathrm{N}_{2}$ frozenmounted sample was then inserted into a cryostat $[\mathrm{He}(1), \sim 25$ $\mathrm{K}$ ], which was then flushed and purged with $\mathrm{He}(\mathrm{g}) 3$ times. The spectra then were recorded in continuous scan mode as transmission data at $\sim 25 \mathrm{~K}$ using a $\mathrm{Si}(220)$ monochromator, which was calibrated to the first-derivative maximum of the Kedge absorption spectrum of metallic Fe foil $(7112 \mathrm{eV})$. Foil was continuously monitored to account for small energy shifts $(<1 \mathrm{eV})$ during the sample measurements. Higher harmonics in the beam were eliminated by use of Si mirrors. 10-15 scans were collected and averaged. Details on data reduction and analyses are given in the Supporting Information (Section S3).

\section{RESULTS AND DISCUSSION}

3.1. Characterization of Vivianite Nanoparticles. The white precipitate obtained in the synthesis was first analyzed by XRD and the resulting diffractogram was consistent with the vivianite structure as shown by Rietveld fitting ${ }^{40}$ (Figure 1a). Only a minor percentage (1.6\%) of metavivianite, the partially oxidized form of vivianite $\mathrm{Fe}^{\mathrm{II}} \mathrm{Fe}^{\mathrm{III}}{ }_{2}\left(\mathrm{PO}_{4}\right)_{2}(\mathrm{OH})_{2} \cdot 6 \mathrm{H}_{2} \mathrm{O},{ }^{41}$ was detected by one small reflection at $12.6^{\circ} 2 \theta$, highlighting the purity of the synthesized vivianite. The spherical morphology of vivianite nanoparticles was evidenced by TEM (Figure 1b) and their good dispersion on the grids allowed for an assessment of the particle size distribution. The size distribution of vivianite nanoparticles was monomodal with a $d_{\text {avg }}$ value of $53 \pm 10 \mathrm{~nm}(n=300$, normal distribution, $p$-value $=0.2$ ), leading to an average SSA distribution (eq 1) of $42.0 \pm$ 


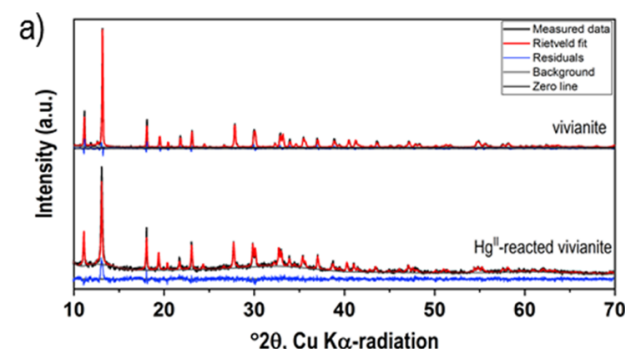

b)
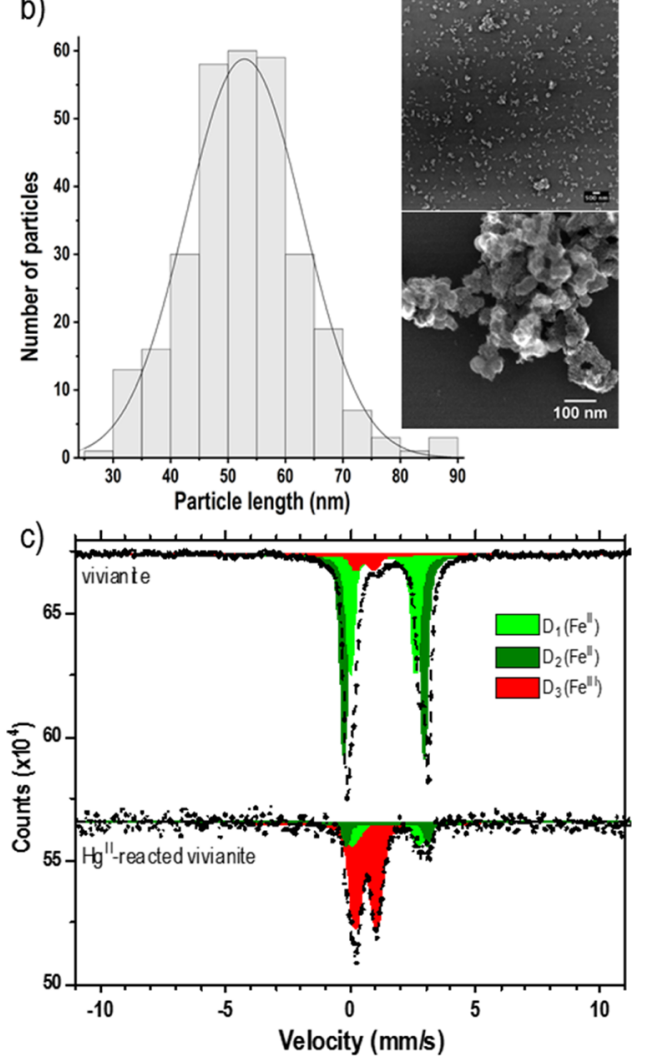

Figure 1. Characterization of unreacted and $\mathrm{Hg}^{\mathrm{II}}$-reacted vivianite: (a) XRD diffractograms of unreacted vivianite (upper graph) and after $24 \mathrm{~h}$ incubation with $\mathrm{Hg}^{\mathrm{II}}$ at a $\mathrm{Fe}^{\mathrm{II}} / \mathrm{Hg}^{\mathrm{II}}$ ratio of 1 (lower graph). (b) Particle size distribution of vivianite nanoparticles, determined from three independent 100-particle samples (inset, STEM-secondary electron image). (c) $77 \mathrm{~K}$ transmission Mössbauer spectra of vivianite at $t=0$ (upper graph) and $t=24 \mathrm{~h}$ (lower graph) were fitted using the presence of three doublets $\mathrm{D}_{1}$ (light green) and $\mathrm{D}_{2}$ (dark green) for structural ferrous iron, and $\mathrm{D}_{3}$ (red) for structural ferric iron.

$0.4 \mathrm{~m}^{2} \mathrm{~g}^{-1}$. This is four times higher than previously reported by Luna-Zaragoza et al. ${ }^{42}$ because of the nanoparticulate nature of the synthesized mineral.
Mössbauer spectroscopy was used to quantify the proportion of $\mathrm{Fe}^{\mathrm{II}}$ and $\mathrm{Fe}^{\mathrm{III}}$ species in solid samples. The Mössbauer spectrum of the unreacted vivianite obtained at 77 $\mathrm{K}$ was fitted with three doublets, $\mathrm{D}_{1}, \mathrm{D}_{2}$, and $\mathrm{D}_{3}$ (Figure 1c) with the corresponding hyperfine parameters, as presented in Table 1 . Doublets $\mathrm{D}_{1}$ and $\mathrm{D}_{2}$ are characterized by large center shift (CS) and quadrupole splitting $\left(\Delta E_{\mathrm{Q}}\right)$ values, which are similar to previously published values for vivianite at $77 \mathrm{~K},{ }^{43,44}$ and correspond to the two $\mathrm{Fe}^{\mathrm{II}}$ octahedral sites. One site corresponds to $\mathrm{Fe}^{2+} \mathrm{O}_{2}\left(\mathrm{H}_{2} \mathrm{O}\right)_{4}$ octahedra where the trans $\mathrm{O}^{2-}$ corners are the apices of $\mathrm{PO}_{4}$ tetrahedra, whereas the second site constitutes $\mathrm{Fe}^{2+} \mathrm{O}_{4}\left(\mathrm{H}_{2} \mathrm{O}\right)_{2}$ octahedra that share edges in pairs. A third doublet $\mathrm{D}_{3}$ is characterized by small CS and $\Delta E_{\mathrm{Q}}$ values of 0.59 and $0.76 \mathrm{~mm} \mathrm{~s}^{-1}$, respectively. These values are typical of $\mathrm{Fe}^{\mathrm{III}}$ and are potentially consistent with those of metavivianite: ${ }^{41,43} \mathrm{CS} \sim 0.43 \mathrm{~mm} \mathrm{~s}^{-1}$ and $\Delta E_{\mathrm{Q}} \sim 0.77-0.87$ $\mathrm{mm} \mathrm{s}^{-1}$. Thus, the contribution of $\mathrm{Fe}^{\mathrm{II}}$ and $\mathrm{Fe}^{\mathrm{III}}$ was estimated at 93.8 and $6.2 \%$, respectively. This indicates that some degree of oxidation occurred but only to a limited extent, possibly during the transfer of the sample into the cryostat.

Shell fit analysis of the Fe K-edge EXAFS spectra for the unreacted vivianite was conducted as a complimentary technique to XRD and Mössbauer to determine local Fe coordination and bond lengths as well as the presence of amorphous phases. The results are shown in Figure S3, and the corresponding fitting parameters are detailed in Table S2. The first coordination shell was fitted with $4.8 \mathrm{O}$ at a distance of $2.13 \AA$ A. Additional paths for $\mathrm{Fe}-\mathrm{Fe}$ (at $3.02 \AA$ ) and $\mathrm{Fe}-\mathrm{P}$ (at $3.35 \AA$ ) were used to fit the second and third shells, respectively. Additional features of the EXAFS spectrum were fitted with $\mathrm{Fe}-\mathrm{Fe}$ paths $\left(\mathrm{Fe}-\mathrm{Fe}_{2-4}\right)$ at ca. 4.7, 5.25, and $6.25 \AA$. These values are in good agreement with theoretical path distances for neighbor shells in $\mathrm{Fe}(\mathrm{II})$ phosphates. ${ }^{45-47}$ The inclusion of an $\mathrm{Fe}-\mathrm{O}$ path and a $\mathrm{Fe}-$ $\mathrm{O}-\mathrm{O}$ multiple scattering path at 3.98 and $4.46 \AA$, respectively, likewise improved the fit.

3.2. Hg Mass Balance and Reaction Stoichiometry with Fe". The ability of vivianite to reduce $\mathrm{Hg}^{\mathrm{II}}$ (initial concentration of $50 \mu \mathrm{mol} \mathrm{L}{ }^{-1}$ ) was first evidenced at $\mathrm{Fe}^{\mathrm{II}} / \mathrm{Hg}^{\mathrm{II}}$ ratio of 1 , where the $\mathrm{Hg}^{0}$ released was trapped and re-oxidized in acidic $\mathrm{KMnO}_{4}$ solution. In contact with vivianite nanoparticles, $\mathrm{Hg}^{\mathrm{II}}$ concentration decreased concomitantly with the production of a roughly equivalent volatile $\mathrm{Hg}^{0}$ concentration (Figure 2), according to an exponential decay (eq 2) and an exponential rise (eq. 3 ), respectively

$$
\begin{aligned}
& {\left[\mathrm{Hg}^{\mathrm{II}}\right]_{t}=\left(\left[\mathrm{Hg}^{\mathrm{II}}\right]_{0}-\left[\mathrm{Hg}^{\mathrm{II}}\right]_{f}\right) \times \mathrm{e}^{-k_{\mathrm{obs}} \times t}+\left[\mathrm{Hg}^{\mathrm{II}}\right]_{f}} \\
& {\left[\mathrm{Hg}^{0}\right]_{t}=\left[\mathrm{Hg}^{0}\right]_{f} \times\left(1-\mathrm{e}^{-k_{\mathrm{obs}} \times t}\right)}
\end{aligned}
$$

\begin{tabular}{|c|c|c|c|c|c|c|}
\hline & type of sites & $\mathrm{CS}\left(\mathrm{mm} \mathrm{s}^{-1}\right)$ & $\Delta E\left(\mathrm{~mm} \mathrm{~s}^{-1}\right)$ & $\sigma\left(\Delta E_{\mathrm{Q}}\right)$ & R.A. (\%) & $\chi^{2}$ \\
\hline \multirow[t]{3}{*}{ unreacted vivianite } & $\mathrm{D}_{1}\left(\mathrm{Fe}^{\mathrm{II}}\right)$ & $1.34 \pm 0.001$ & $3.22 \pm 0.004$ & 0.08 & $56.4 \pm 0.8$ & 0.85 \\
\hline & $\mathrm{D}_{2}\left(\mathrm{Fe}^{\mathrm{II}}\right)$ & $1.30 \pm 0.002$ & $2.62 \pm 0.009$ & 0.15 & $37.4 \pm 0.8$ & \\
\hline & $\mathrm{D}_{3}\left(\mathrm{Fe}^{\mathrm{III}}\right)$ & $0.59 \pm 0.027$ & $0.76 \pm 0.043$ & 0.30 & $6.2 \pm 0.4$ & \\
\hline \multirow[t]{3}{*}{$\mathrm{Hg}^{\mathrm{II}}$-reacted vivianite } & $\mathrm{D}_{1}\left(\mathrm{Fe}^{\mathrm{II}}\right)$ & $1.34 \pm 0.002$ & $3.23 \pm 0.005$ & 0.00 & $10.3 \pm 0.1$ & 0.59 \\
\hline & $\mathrm{D}_{2}\left(\mathrm{Fe}^{\mathrm{II}}\right)$ & $1.31 \pm 0.004$ & $2.64 \pm 0.012$ & 0.14 & $16.8 \pm 0.4$ & \\
\hline & $\mathrm{D}_{3}\left(\mathrm{Fe}^{\mathrm{III}}\right)$ & $0.50 \pm 0.090$ & $0.83 \pm 0.120$ & 0.48 & $72.9 \pm 0.1$ & \\
\hline
\end{tabular}

Table 1. Mössbauer Hyperfine Parameters at $77 \mathrm{~K}$ of Unreacted and $\mathrm{Hg}^{\mathrm{II}}$-Reacted Vivianite ${ }^{a}$

${ }^{a} \mathrm{CS}$ is the center shift with respect to $\alpha$-Fe $\left(\mathrm{mm} \mathrm{s}^{-1}\right), \Delta E_{\mathrm{Q}}$ the quadrupole splitting $\left(\mathrm{mm} \mathrm{s}^{-1}\right)$, with $\sigma\left(\Delta E_{\mathrm{Q}}\right)$ indicating sigma broadening of the quadrupole splitting, R.A. the relative abundance of each site (\%), and $\chi^{2}$ the goodness of fit. D refers to each doublet used during fitting. 


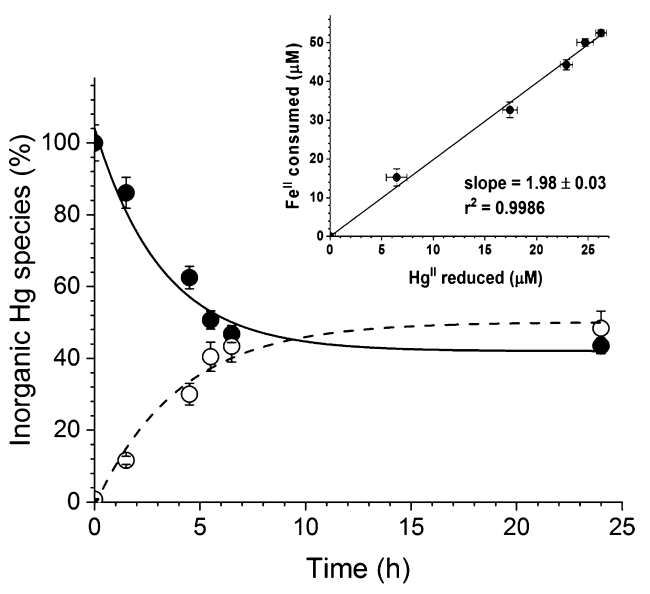

Figure 2. Time courses of inorganic $\mathrm{Hg}$ species $\left(\mathrm{Hg}^{\mathrm{II}}\right.$ : close circles, $\mathrm{Hg}^{0}$ : open circles) during the reduction of $\mathrm{Hg}^{\mathrm{II}}$ by vivianite at a $\mathrm{Fe}^{\mathrm{II}}$ / $\mathrm{Hg}^{\mathrm{II}}$ ratio of 1 with an initial $\mathrm{Hg}^{\mathrm{II}}$ concentration of $50 \mu \mathrm{mol} \mathrm{L}^{-1}$. The inset shows the $\mathrm{Fe}^{\mathrm{II}}$ consumption as a function of the $\mathrm{Hg}^{\mathrm{II}}$ reduction between 0 and $6 \mathrm{~h}$. Error bars represent standard deviation for two independent assays.

where $\left[\mathrm{Hg}^{\mathrm{II}}\right]_{0}$ and $\left[\mathrm{Hg}^{0}\right]_{0}$ are the initial concentrations of cationic divalent mercury and elemental mercury, respectively; $\left[\mathrm{Hg}^{\mathrm{II}}\right]_{f}$ and $\left[\mathrm{Hg}^{0}\right]_{f}$ are the concentrations of cationic divalent mercury and elemental mercury at the plateau, respectively; and $k_{\text {obs }}$ is the apparent rate coefficient $\left(\mathrm{min}^{-1}\right)$. After a $6 \mathrm{~h}$ incubation period, a color change was observed in the $\mathrm{KMnO}_{4}$ solution from dark purple to colorless (Figure S2), and the reaction between $\mathrm{Hg}^{\mathrm{II}}$ and vivianite was almost complete with a $\mathrm{Hg}^{\mathrm{II}}$ reduction of $46 \pm 3 \%$ and an equivalent release of $\mathrm{Hg}^{0}$. The stoichiometry of the redox reaction between $\mathrm{Fe}^{\mathrm{II}}$ and $\mathrm{Hg}^{\mathrm{II}}$ was determined to be $1.98 \pm 0.03$ (Figure 2), in agreement with the expected stoichiometry involving the oxidation of 2 mol of $\mathrm{Fe}^{\mathrm{II}}$ to $\mathrm{Fe}^{\mathrm{III}}$ for the reduction of $1 \mathrm{~mol} \mathrm{Hg}^{\mathrm{II}}$ to $\mathrm{Hg}^{0}$. In this case, the $\mathrm{Hg}$ mass balance reached $92 \pm 1 \%$ and the missing fraction is likely liquid $\mathrm{Hg}^{0}$ that remained bound to vivianite, which is then lost during the acidification of the suspension. The elemental distribution maps presented in Figure 3 clearly show the presence of spherical or platy $\mathrm{Hg}$ enrichments, with a homogeneous size distribution ranging from about 20 to $40 \mathrm{~nm}$ (average $28 \pm 5 \mathrm{~nm}, n=37$ ) associated with vivianite. No other element was detected in association with $\mathrm{Hg}$, suggesting that these enrichments consisted of nanodroplets of $\mathrm{Hg}^{0}$. The formation of liquid $\mathrm{Hg}^{0}$ is favored under our experimental conditions with high $\mathrm{Hg}$ concentrations because its solubility is $0.3 \mu \mathrm{mol} \mathrm{L}{ }^{-1}$, but it is however questionable if $\mathrm{Hg}^{0}$ formed under environmental conditions would also remained associated with the mineral phases. Bouffard and Amyot ${ }^{48}$ found a significant proportion of the total $\mathrm{Hg}$ as $\mathrm{Hg}^{0}$ in the solid fraction of lake sediments (up to $28 \%$ ) and hypothesized that $\mathrm{Hg}^{0}$ formed in porewater and then adsorbs to the solid phase through OM. Our finding represents an alternative explanation to why $\mathrm{Hg}^{0}$ can be found associated with solid phases in soils and sediments.

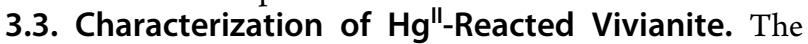
changes in the $\mathrm{Fe}$ redox state and mineralogy of the $\mathrm{Hg}^{\mathrm{II}}$ reacted vivianite were investigated for a $\mathrm{Fe}^{\mathrm{II}} / \mathrm{Hg}^{\mathrm{II}}$ ratio of 1 $\left(\left[\mathrm{Hg}^{\mathrm{II}}\right]_{0}=50 \mu \mathrm{mol} \mathrm{L}-1\right)$ and the $\mathrm{Fe}$ oxidation was visually confirmed when the mineral color changed from white to dark blue, typical of oxidized vivianite. ${ }^{49}$ The chemical analysis of the reacted vivianite by the ferrozine method indicated that 76 $\pm 6 \%$ of $\mathrm{Fe}^{\mathrm{II}}$ was oxidized to $\mathrm{Fe}^{\mathrm{III}}$ during $\mathrm{Hg}^{\mathrm{II}}$ reduction (data
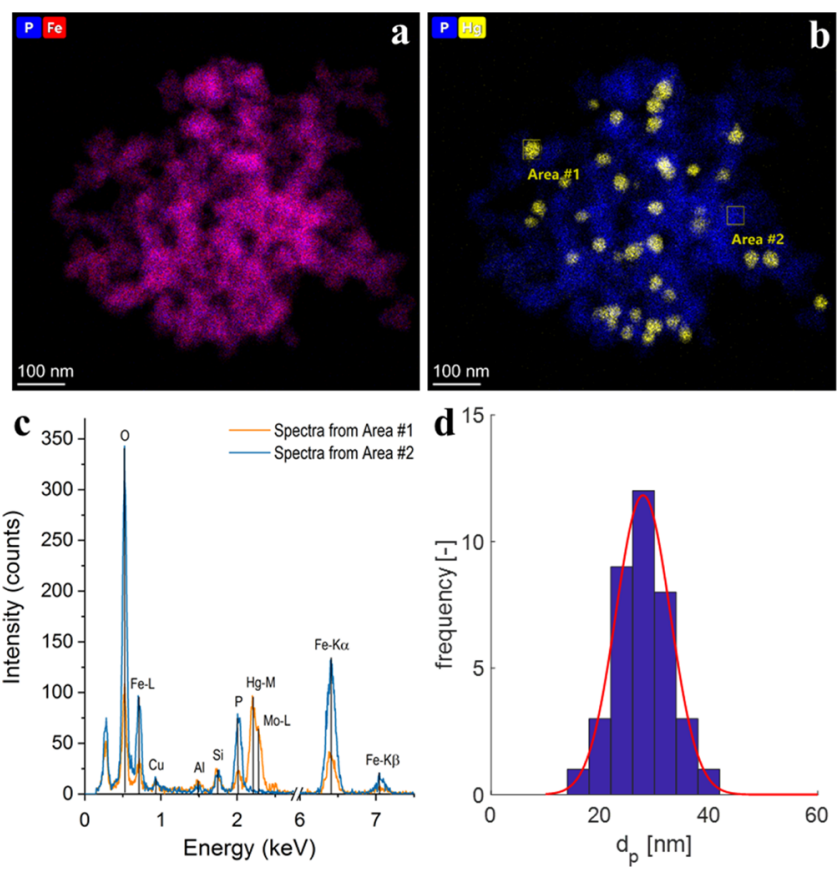

Figure 3. Elemental distribution of $\mathrm{Hg}^{\mathrm{II}}$-reacted vivianite at a $\mathrm{Fe}^{\mathrm{II}}$ / $\mathrm{Hg}^{\mathrm{II}}$ ratio of 1 after $5 \mathrm{~h}$ of reaction. The violet color of vivianite nanoparticles (a) results from the combination of $\mathrm{Fe}$ (red) and $\mathrm{P}$ (blue) colors. $\mathrm{Hg}$ enrichments (yellow) are clearly seen associated with vivianite after $\mathrm{Hg}^{\mathrm{II}}$ reduction (b). Two spectra (c) were extracted from the elemental distribution maps for a $\mathrm{Hg}$ enrichment (b, area $\# 1)$ and vivianite nanoparticle (b, area \#2) and the size distribution of the $\mathrm{Hg}$ enrichments was also estimated (d).

not shown). Three doublets $\mathrm{D}_{1}, \mathrm{D}_{2}$, and $\mathrm{D}_{3}$ were also required to fit the Mössbauer spectrum of the reacted vivianite (Figure 1c and Table 1). The CS and $\Delta E_{\mathrm{Q}}$ values were close to those obtained for the unreacted vivianite but the contribution of $\mathrm{Fe}^{\mathrm{II}}$ and $\mathrm{Fe}^{\mathrm{III}}$ was reversed with $27.1 \pm 0.3$ and $72.9 \pm 0.1 \%$, respectively. Along with the reduction of $\mathrm{Hg}^{\text {II }}$ by vivianite, the Mössbauer data indicated a decrease of the $\mathrm{Fe}^{\mathrm{II}} / \mathrm{Fe}_{\mathrm{TOT}}$ ratio from 0.95 to 0.23 , in agreement with the results of the chemical analyses.

The average diameter of the $\mathrm{Hg}^{\mathrm{II}}$-reacted nanoparticles remained similar to the initial vivianite, that is, $45 \pm 5 \mathrm{~nm}$ (data not shown) and the XRD diffractogram of the $\mathrm{Hg}^{\mathrm{II}}$ reacted vivianite was essentially the same as the starting material but with the presence of a small background feature (Figure 1a), which was interpreted as being from an amorphous phase(s), most likely ferric phosphate. Rouzies and Millet $^{50}$ already demonstrated that upon air oxidation at room temperature the monoclinic crystal system of vivianite was maintained until about $50 \%$ of the iron was present as $\mathrm{Fe}^{\mathrm{III}}$ and then alters to metavivianite. In our sample that was not exposed to air, no formation of crystalline metavivianite could be detected beyond the small amount originally present. Altogether, our results suggest that a significant proportion of the $\mathrm{Fe}$ is present as oxidized vivianite, which structural integrity was maintained after oxidation by $\mathrm{Hg}^{\mathrm{II}}$. This oxidized vivianite could potentially be regenerated under reducing conditions, as previously demonstrated for green rust ${ }^{51}$ and magnetite, ${ }^{39,52}$ and serves several times as an electron donor but this warrants further investigations.

3.4. Kinetics of $\mathbf{H g}^{\text {"l }}$ Reduction by Vivianite. Significant $\mathrm{Hg}^{\mathrm{II}}$ reduction occurred in vivianite suspensions with $\mathrm{Fe}^{\mathrm{II}} / \mathrm{Hg}^{\mathrm{II}}$ 
ratios of 1000, 100, and 1 but not at 0.1 (Figures 4a and S4). Control tests performed without vivianite or with free $\mathrm{Fe}^{2+}{ }_{\mathrm{aq}}$

a)

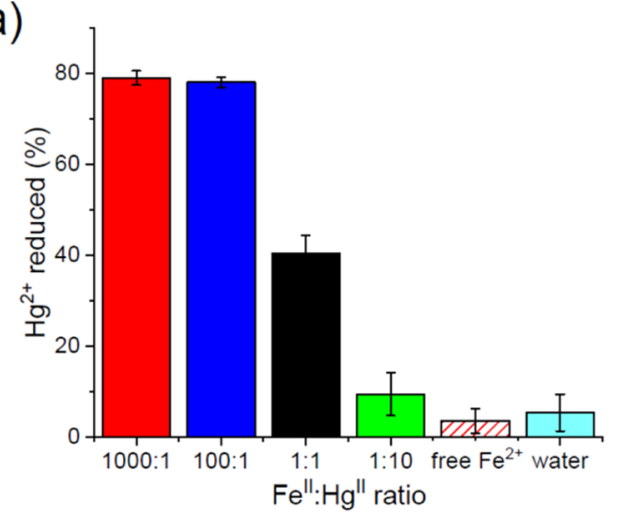

b)

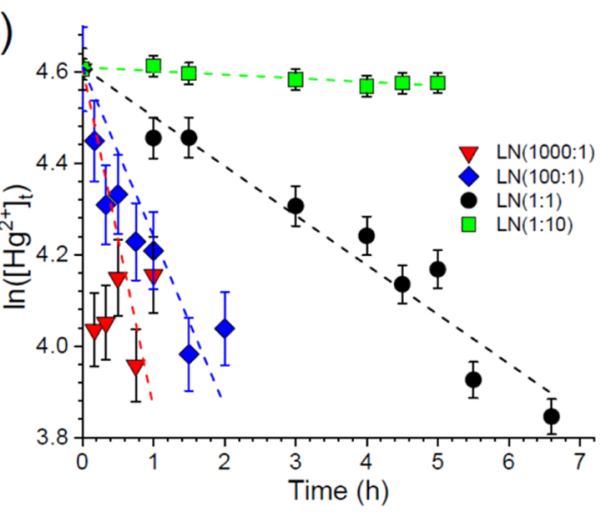

Figure 4. Reduction of $\mathrm{Hg}^{\mathrm{II}}$ by vivianite. (a) Percent $\mathrm{Hg}^{\mathrm{II}}$ reduced in suspension $24 \mathrm{~h}$ after its spike at $0.50 \mu \mathrm{mol} \mathrm{L}-1$. Four $\mathrm{Fe}^{\mathrm{II}} / \mathrm{Hg}^{\mathrm{II}}$ ratios were studied: 1000 (red), 100 (blue), 1 (black), and 0.1 (green). Two control experiments were performed with free $\mathrm{Fe}^{2+}$ (red stripes) and deoxygenated water (light blue). (b) Linearized kinetic data with dotted lines indicating the pseudo first-order law fit for $\mathrm{Fe}^{\mathrm{II}} / \mathrm{Hg}^{\mathrm{II}}$ ratios of 1000 (red triangles), 100 (blue diamonds), 1 (black circles), and 0.1 (green squares). Error bars represent standard deviation of experimental replicates $(n=2-5)$.

(50 $\mu \mathrm{mol} \mathrm{L}^{-1}$ ) did not lead to a significant removal of $\mathrm{Hg}^{\mathrm{II}}$ (less than $5 \%$ in both cases) over the $24 \mathrm{~h}$ of the experiment.
This indicates that $\mathrm{Hg}^{\mathrm{II}}$ losses observed in the presence of vivianite were neither because of sorption onto the vessel walls or Teflon caps, nor because of reduction by free aqueous $\mathrm{Fe}^{\mathrm{II}}$ species.

For $\mathrm{Fe}^{\mathrm{II}} / \mathrm{Hg}^{\mathrm{II}}$ ratios greater than or equal to $1, \mathrm{Hg}^{\mathrm{II}}$ reduction can be described by a pseudo first-order reaction (Figure S4, all fits presenting $r^{2} \geq 0.91$ ), which is consistent with previous studies performed on $\mathrm{Hg}^{\mathrm{II}}$ removal in the presence of $\mathrm{Fe}^{\mathrm{II}}$-bearing minerals. ${ }^{16-20}$ Before $1 \mathrm{~h}$ (Figure $4 \mathrm{~b}$ ), the data for the 100:1 ratio show a slightly higher degree of scattering around the linear model, while for the 1000:1 ratio, the data do not fit the linear model. This is likely because the reaction is too fast with this large excess of $\mathrm{Fe}$ and the time sampling did not adequately resolve that period. However, when considering the other ratios and previous studies, it is very likely that the reaction also follows a pseudo-first order kinetic, given the large excess of Fe. The $k_{\text {obs }}$ values of $1.80 \pm$ $0.03 \times 10^{-3}, 6.17 \pm 0.07 \times 10^{-3}$, and $11.7 \pm 0.3 \times 10^{-3} \mathrm{~min}^{-1}$, obtained for $\mathrm{Fe}^{\mathrm{II}} / \mathrm{Hg}^{\mathrm{II}}$ ratios of 1,100 , and 1000 , respectively, were in the same order of magnitude as those reported for siderite, $^{20}$ carbonate green rust, ${ }^{18}$ and magnetite ${ }^{16}$ (Table 2). As expected, the higher the $\mathrm{Fe}^{\mathrm{II}}$ concentration, the faster the rate of $\mathrm{Hg}^{\mathrm{II}}$ reduction. However, for both $\mathrm{Fe}^{\mathrm{II}} / \mathrm{Hg}^{\mathrm{II}}$ ratios of 100 and 1000, the reaction was still not complete after $24 \mathrm{~h}$, and $20 \%$ of the added $\mathrm{Hg}$ remained as $\mathrm{Hg}^{\mathrm{II}}$, suggesting that a fraction of $\mathrm{Hg}$ was non-specifically adsorbed to vivianite. To allow a better comparison of the $\mathrm{Hg}$ reduction kinetic with other $\mathrm{Fe}^{\mathrm{II}}$-bearing minerals, it is crucial to consider the $\mathrm{Fe}^{\mathrm{II}}$ surface site concentration and the $\mathrm{Fe}^{\mathrm{II}} / \mathrm{Hg}^{\mathrm{II}}$ ratio. In previous studies investigating $\mathrm{Hg}^{\mathrm{II}}$ removal by microcrystalline $\mathrm{Fe}$ minerals, ${ }^{18}$ the SSA $\left(\mathrm{m}^{2} \mathrm{~g}^{-1}\right)$ was evaluated by $\mathrm{N}_{2}$-BET measurements. Here, $A_{\text {vivianite }}$ was calculated to be $3.68 \mathrm{~m}^{2} \mathrm{~L}^{-1}$ according to the following equation

$$
A_{\text {vivianite }}=\mathrm{SSA} \times \mathrm{MW} \times\left[\mathrm{Fe}_{3}^{\mathrm{II}}\left(\mathrm{PO}_{4}\right)_{2} \cdot 8 \mathrm{H}_{2} \mathrm{O}\right]
$$

where SSA is the SSA $\left(42.0 \mathrm{~m}^{2} \mathrm{~g}^{-1}\right.$, estimated from the size of the vivianite nanoparticles as described in the Materials and Methods section), MW is vivianite's molecular weight (501.61 $\left.\mathrm{g} \mathrm{mol}^{-1}\right)$, and $\left[\mathrm{Fe}_{3}{ }_{3}\left(\mathrm{PO}_{4}\right)_{2} \cdot 8 \mathrm{H}_{2} \mathrm{O}\right]$ is the actual concentration of $\mathrm{Fe}$ in vivianite $\left(500 \mu \mathrm{mol} \mathrm{L} \mathrm{L}^{-1}\right.$ of $\mathrm{Fe}$ corresponding to a vivianite concentration of $\left.167 \mu \mathrm{mol} \mathrm{L}{ }^{-1}\right)$. Because the average value of vivianite surface site density is $6 \mathrm{Fe}^{\mathrm{II}}$ sites per $\mathrm{nm}^{2}$, 33

Table 2. Comparison of Kinetics Parameters for $\mathrm{Hg}^{\mathrm{II}}$ Reduction by Vivianite, Siderite, Green Rusts, and Magnetite at Circumneutral pH under Anoxic Conditions ${ }^{a}$

\begin{tabular}{|c|c|c|c|c|c|c|}
\hline & $\mathrm{Fe}^{\mathrm{II}} / \mathrm{Hg}^{\mathrm{II}}$ ratio & $A\left(\mathrm{~m}^{2} \mathrm{~L}^{-1}\right)$ & $\mathrm{Fe}^{\mathrm{II}}$ surface site $\left(\mu \mathrm{mol} \mathrm{L}^{-1}\right)$ & $k_{\text {obs }}\left(\times 10^{-3} \min ^{-1}\right)$ & $k_{\mathrm{S}}\left(\mathrm{L} \mathrm{mmol}{ }^{-1} \min ^{-1}\right)$ & $t_{1 / 2}(\min )$ \\
\hline \multirow[t]{4}{*}{ vivianite $^{b}$} & 1000 & 3.68 & 36.7 & 11.7 & 0.32 & 59 \\
\hline & 100 & $3.68 \times 10^{-1}$ & 3.67 & 6.17 & 1.68 & 112 \\
\hline & 1 & $3.68 \times 10^{-3}$ & $3.67 \times 10^{-2}$ & 1.80 & 49 & 385 \\
\hline & 0.1 & $3.68 \times 10^{-4}$ & $3.67 \times 10^{-3}$ & 0.14 & 38 & 4951 \\
\hline \multirow[t]{3}{*}{ siderite $^{c}$} & 31,382 & 24.72 & 246 & 14.7 & 0.06 & 47 \\
\hline & 15,691 & 12.36 & 123 & 20.4 & 0.17 & 34 \\
\hline & 7855 & 6.18 & 62 & 13.9 & 0.22 & 50 \\
\hline \multirow[t]{2}{*}{ green rusts $^{d}$} & $400^{e}$ & 10 & 83 & 28 & 0.34 & 25 \\
\hline & $400^{f}$ & 4.6 & 38.2 & 130 & 3.40 & 5 \\
\hline \multirow[t]{3}{*}{ magnetite ${ }^{g}$} & 8300 & 2.0 & 75.2 & 96 & 1.3 & 7 \\
\hline & 4150 & 1.0 & 37.6 & 54 & 1.4 & 13 \\
\hline & 2075 & 0.5 & 18.8 & 24 & 1.3 & 29 \\
\hline
\end{tabular}

${ }^{a}$ Kinetic rate coefficients $\left(k_{\mathrm{obs}}, \mathrm{min}^{-1}\right)$ normalized to the $\mathrm{Fe}^{\mathrm{II}}$ surface site concentration $\left(k_{\mathrm{S}}, \mathrm{L} \mathrm{mmol}{ }^{-1} \mathrm{~min}^{-1}\right)$ by taking into account the mineral surface area concentration $\left(A, \mathrm{~m}^{2} \mathrm{~L}^{-1}\right) . \mathrm{Hg}^{\mathrm{II}}$ half-life $\left(t_{1 / 2}, \mathrm{~min}\right)$ of the pseudo first-order reaction is calculated from $\ln (2) / k_{\mathrm{obs}} \cdot{ }^{b_{\mathrm{T}}} \mathrm{This}$ study. ${ }^{c}$ Reference $20 .{ }^{d}$ Reference $18 .{ }^{e}$ Carbonate green rust. ${ }^{f}$ Sulphate green rust. ${ }^{g}$ Reference 16. 
vivianite should have $2.2 \times 10^{19} \mathrm{Fe}^{\mathrm{II}}$ sites $\mathrm{L}^{-1}$ (i.e., $6 \times 3.68 \times$ $\left.10^{18} \mathrm{~nm}^{2} \mathrm{~L}^{-1}\right)$ and a total concentration of $\mathrm{Fe}^{\mathrm{II}}$ surface sites of $36.7 \mu \mathrm{mol} \mathrm{L}^{-1}$ (Table 2). Thus, $k_{\text {obs }}$ values were normalized to the total concentration of $\mathrm{Fe}^{\mathrm{II}}$ surface sites to define $k_{\mathrm{s}}$ values, and the ability of vivianite to reduce $\mathrm{Hg}^{\mathrm{II}}$ is similar to those of carbonate green rust ${ }^{18}$ and siderite ${ }^{20}$ at $\mathrm{Fe}^{\mathrm{II}} / \mathrm{Hg}^{\mathrm{II}}$ ratios of 400 and 7855, respectively. Nonetheless, the interpretation of $t_{1 / 2}$ values in regard to $\mathrm{Fe}^{\mathrm{II}} / \mathrm{Hg}^{\mathrm{II}}$ ratios should place vivianite as an ideal candidate to reduce $\mathrm{Hg}^{\mathrm{II}}$ to $\mathrm{Hg}^{0}$ in $\mathrm{Fe}^{\mathrm{II}}$ and P-rich environments, such as in freshwater or coastal sediments where the vivianite $/ \mathrm{Hg}^{\mathrm{II}}$ ratio is potentially even higher than the maximum $\mathrm{Fe}^{\mathrm{II}} / \mathrm{Hg}^{\mathrm{II}}$ ratio $(1000: 1)$ studied here.

3.5. Environmental Implications. In the present study, we demonstrated that $\mathrm{Hg}^{\mathrm{II}}$ is efficiently reduced by vivianite, with reaction yield and kinetics similar to those of carbonate green rust and siderite, considered up to now as the two most effective $\mathrm{Fe}^{\mathrm{II}}$ minerals for $\mathrm{Hg}$ reduction. In P-rich environments, this pathway deserves special attention considering that the reactivity of green rusts is severely decreased in the presence of even low amounts of phosphates ${ }^{18,54,55}$ and that vivianite could potentially be regenerated under reducing conditions as demonstrated for other Fe minerals. ${ }^{39,51,52}$ The reducing capacity of vivianite toward $\mathrm{Hg}^{\mathrm{II}}$, however, requires further investigations, especially regarding the impact of dissolved organic ligands that may decrease the availability of $\mathrm{Hg}$, and the presence of competing ions, such as chloride. ${ }^{21}$ Nonetheless, this represents a newly discovered pathway for $\mathrm{Hg}$ reduction which could be of significant environmental relevance for the $\mathrm{Hg}$ biogeochemical cycle because vivianite has been detected worldwide in various settings. It might be especially important in organic-poor environments where the speciation of dissolved $\mathrm{Hg}$ is shifted toward inorganic $\mathrm{Hg}$ complexes, such as coastal sediments and groundwaters. Because of the presence of strong organic ligands, the reaction might be slower and/or quantitatively less important in organic-rich environments, such as eutrophic aquatic ecosystems, wastewater sludges, and paddy or organic soils where vivianite and $\mathrm{Hg}$ accumulates ${ }^{23}$ but this would need to be systematically studied. While the methylation and re-emission of $\mathrm{Hg}$ from thawing permafrost soils is now attracting much attention, ${ }^{56,57}$ vivianite was recently shown to be the main $\mathrm{Fe}^{\mathrm{II}}$ bearing mineral in organic horizons of an arctic tundra soil. ${ }^{58}$

The formation of vivianite under reducing microenvironments is also relevant for $\mathrm{Hg}$ methylation that also occur in these microniches, including in otherwise oxic and suboxic compartments. In lakes and reservoirs, it has been demonstrated that $\mathrm{Hg}$ methylation is promoted by eutrophication, ${ }^{59-61}$ and thus the phosphorus delivery to the ecosystem. Sulfur-poor, $\mathrm{Fe}$ and organic/P-rich soils and sediments are potential hotspots for $\mathrm{Hg}$ methylation, where $\mathrm{Hg}^{\mathrm{II}}$ is efficiently methylated by dissimilatory $\mathrm{Fe}$ (III) reducing bacteria, ${ }^{62-64}$ such as Shewanella oneidensis MR-1, Geobacter sulfurreducens PCA, and Geobacter metallireducens GS-15. ${ }^{65-67}$ However, it was also observed that the production of $\mathrm{MeHg}$ was suppressed in the presence of high concentrations of Fe. This was speculated to be caused by the scavenging of $\mathrm{Hg}$ by $\mathrm{Fe}$ minerals and/or its microbial reduction, ${ }^{62,63,67}$ but the reduction of $\mathrm{Hg}^{\mathrm{II}}$ by authigenic $\mathrm{Fe}^{\mathrm{II}}$-bearing minerals, including vivianite, should also be considered as a competitive pathway to methylation in such environments, thereby limiting its subsequent bioaccumulation.

\section{ASSOCIATED CONTENT}

\section{s) Supporting Information}

The Supporting Information is available free of charge at https://pubs.acs.org/doi/10.1021/acs.est.0c05203.

Conditions of vivianite synthesis and characterization; elemental mercury trapping setup and experimental conditions for $\mathrm{Hg}^{\mathrm{II}}$ reduction; bulk Fe XAS analysis of unreacted vivianite and associated shell-fit parameters; and data for $\mathrm{Hg}^{\mathrm{II}}$ reduction by vivianite at various $\mathrm{Fe}^{\mathrm{II}}$ / $\mathrm{Hg}^{\mathrm{II}}$ ratios $(\mathrm{PDF})$

\section{AUTHOR INFORMATION}

\section{Corresponding Author}

Sylvain Bouchet - Soil Chemistry Group, Institute of Biogeochemistry and Pollutant Dynamics, Department of Environmental Systems Science, ETH Zürich, 8092 Zürich, Switzerland; 이이.org/0000-0002-5753-9643; Phone: +41 4463360 24; Email: sylvain.bouchet@ usys.ethz.ch

\section{Authors}

Marjorie Etique - Soil Chemistry Group, Institute of Biogeochemistry and Pollutant Dynamics, Department of Environmental Systems Science, ETH Zürich, 8092 Zürich, Switzerland; 이이.org/0000-0002-7699-1897

James M. Byrne - School of Earth Sciences, University of

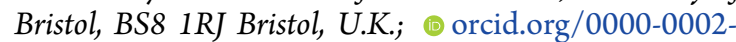
4399-7336

Laurel K. ThomasArrigo - Soil Chemistry Group, Institute of Biogeochemistry and Pollutant Dynamics, Department of Environmental Systems Science, ETH Zürich, 8092 Zürich, Switzerland; 이이.orcido000-0002-6758-3760

Ralf Kaegi - Eawag, Swiss Federal Institute of Aquatic Science and Technology, 8600 Dübendorf, Switzerland; (1) orcid.org/0000-0002-2430-4733

Ruben Kretzschmar - Soil Chemistry Group, Institute of Biogeochemistry and Pollutant Dynamics, Department of Environmental Systems Science, ETH Zürich, 8092 Zürich, Switzerland; 이이이.org/0000-0003-2587-2430

Complete contact information is available at: https://pubs.acs.org/10.1021/acs.est.0c05203

\section{Notes}

The authors declare no competing financial interest.

\section{ACKNOWLEDGMENTS}

The authors are grateful to K. Barmettler, N. Van Groeningen, and K. Hoffmann (ETH Zurich) for assisting with laboratory analyses and sample preparation. We acknowledge SOLEIL for the provision beamtime at the SAMBA beamline and thank G. Landrot and E. Fonda for support during the measurements. We acknowledge the Scientific Center for Optical and Electron Microscopy (ScopeM) of the ETH Zürich for providing access to their microscopes. This research was supported by an ETH postdoctoral grant to M.E. and funding from the European Research Council (ERC) under the European Union's Horizon 2020 research and innovation programme (788009IRMIDYN-ERC-2017-ADG).

\section{REFERENCES}

(1) Selin, N. E. Global Biogeochemical Cycling of Mercury: A Review. Annu. Rev. Environ. Resour. 2009, 34, 43-63. 
(2) Outridge, P. M.; Mason, R. P.; Wang, F.; Guerrero, S.; Heimbürger-Boavida, L. E. Updated Global and Oceanic Mercury Budgets for the United Nations Global Mercury Assessment 2018. Environ. Sci. Technol. 2018, 52, 11466-11477.

(3) Hintelmann, H. Organomercurials. Their Formation and Pathways in the Environment. Met. Ions Life Sci. 2010, 7, 365-401.

(4) Lavoie, R. A.; Jardine, T. D.; Chumchal, M. M.; Kidd, K. A.; Campbell, L. M. Biomagnification of Mercury in Aquatic Food Webs: A Worldwide Meta-Analysis. Environ. Sci. Technol. 2013, 47, 1338513394.

(5) Tsui, M. T.-K.; Liu, S.; Brasso, R. L.; Blum, J. D.; Kwon, S. Y.; Ulus, Y.; Nollet, Y. H.; Balogh, S. J.; Eggert, S. L.; Finlay, J. C. Controls of Methylmercury Bioaccumulation in Forest Floor Food Webs. Environ. Sci. Technol. 2019, 53, 2434-2440.

(6) Clarkson, T. W.; Magos, L. The Toxicology of Mercury and Its Chemical Compounds. Crit. Rev. Toxicol. 2006, 36, 609-662.

(7) Agnan, Y.; Le Dantec, T.; Moore, C. W.; Edwards, G. C.; Obrist, D. New Constraints on Terrestrial Surface-Atmosphere Fluxes of Gaseous Elemental Mercury Using a Global Database. Environ. Sci. Technol. 2016, 50, 507-524.

(8) Amyot, M.; Gill, G. A.; Morel, F. M. M. Production and Loss of Dissolved Gaseous Mercury in Coastal Seawater. Environ. Sci. Technol. 1997, 31, 3606-3611.

(9) Poulain, A. J.; Amyot, M.; Findlay, D.; Telor, S.; Barkay, T.; Hintelmann, H. Biological and Photochemical Production of Dissolved Gaseous Mercury in a Boreal Lake. Limnol. Oceanogr. 2004, 49, 2265-2275.

(10) Barkay, T.; Miller, S. M.; Summers, A. O. Bacterial Mercury Resistance from Atoms to Ecosystems. FEMS Microbiol. Rev. 2003, 27, 355-384.

(11) Wiatrowski, H. A.; Ward, P. M.; Barkay, T. Novel Reduction of Mercury(II) by Mercury-Sensitive Dissimilatory Metal Reducing Bacteria. Environ. Sci. Technol. 2006, 40, 6690-6696.

(12) Hu, H.; Lin, H.; Zheng, W.; Rao, B.; Feng, X.; Liang, L.; Elias, D. A.; Gu, B. Mercury Reduction and Cell-Surface Adsorption by Geobacter Sulfurreducens PCA. Environ. Sci. Technol. 2013, 47, 10922-10930.

(13) Jiang, T.; Skyllberg, U.; Wei, S.; Wang, D.; Lu, S.; Jiang, Z.; Flanagan, D. C. Modeling of the Structure-Specific Kinetics of Abiotic, Dark Reduction of $\mathrm{Hg}(\mathrm{II})$ Complexed by $\mathrm{O} / \mathrm{N}$ and $\mathrm{S}$ Functional Groups in Humic Acids While Accounting for TimeDependent Structural Rearrangement. Geochim. Cosmochim. Acta 2015, 154, 151-167.

(14) Gu, B.; Bian, Y.; Miller, C. L.; Dong, W.; Jiang, X.; Liang, L. Mercury Reduction and Complexation by Natural Organic Matter in Anoxic Environments. Proc. Natl. Acad. Sci. U.S.A. 2011, 108, 14791483.

(15) Charlet, L.; Bosbach, D.; Peretyashko, T. Natural Attenuation of TCE, As, Hg Linked to the Heterogeneous Oxidation of $\mathrm{Fe}(\mathrm{II})$ : An AFM Study. Chem. Geol. 2002, 190, 303-319.

(16) Wiatrowski, H. A.; Das, S.; Kukkadapu, R.; Ilton, E. S.; Barkay, T.; Yee, N. Reduction of $\mathrm{Hg}(\mathrm{II})$ to $\mathrm{Hg}(0)$ by Magnetite. Environ. Sci. Technol. 2009, 43, 5307-5313.

(17) O’Loughlin, E. J.; Kelly, S. D.; Kemner, K. M.; Csencsits, R.; Cook, R. E. Reduction of AgI, AuIII, CuII, and Hg II by FeII/FeIII Hydroxysulfate Green Rust. Chemosphere 2003, 53, 437-446.

(18) Remy, P.-P.; Etique, M.; Hazotte, A. A.; Sergent, A.-S.; Estrade, N.; Cloquet, C.; Hanna, K.; Jorand, F. P. A. Pseudo-First-Order Reaction of Chemically and Biologically Formed Green Rusts with $\mathrm{HgII}$ and $\mathrm{C} 15 \mathrm{H} 15 \mathrm{~N} 3 \mathrm{O} 2$ : Effects of $\mathrm{PH}$ and Stabilizing Agents (Phosphate, Silicate, Polyacrylic Acid, and Bacterial Cells). Water Res. 2015, 70, 266-278.

(19) Bone, S. E.; Bargar, J. R.; Sposito, G. Mackinawite (FeS) Reduces Mercury(II) under Sulfidic Conditions. Environ. Sci. Technol. 2014, 48, 10681-10689.

(20) Ha, J.; Zhao, X.; Yu, R.; Barkay, T.; Yee, N. Hg(II) Reduction by Siderite (FeCO3). Appl. Geochem. 2017, 78, 211-218.

(21) Pasakarnis, T. S.; Boyanov, M. I.; Kemner, K. M.; Mishra, B.; O’Loughlin, E. J.; Parkin, G.; Scherer, M. M. Influence of Chloride and $\mathrm{Fe}(\mathrm{II})$ Content on the Reduction of $\mathrm{Hg}(\mathrm{II})$ by Magnetite. Environ. Sci. Technol. 2013, 47, 6987-6994.

(22) Mishra, B.; O’Loughlin, E. J.; Boyanov, M. I.; Kemner, K. M. Binding of $\mathrm{HgII}$ to High-Affinity Sites on Bacteria Inhibits Reduction to Hg0 by Mixed FeII/III Phases. Environ. Sci. Technol. 2011, 45, 9597-9603.

(23) Rothe, M.; Kleeberg, A.; Hupfer, M. The Occurrence, Identification and Environmental Relevance of Vivianite in Waterlogged Soils and Aquatic Sediments. Earth Sci. Rev. 2016, 158, 51-64.

(24) Rothe, M.; Kleeberg, A.; Grüneberg, B.; Friese, K.; Pérez-Mayo, M.; Hupfer, M. Sedimentary Sulphur:Iron Ratio Indicates Vivianite Occurrence: A Study from Two Contrasting Freshwater Systems. PloS One 2015, 10, No. e0143737.

(25) Dijkstra, N.; Kraal, P.; Kuypers, M. M. M.; Schnetger, B.; Slomp, C. P. Are Iron-Phosphate Minerals a Sink for Phosphorus in Anoxic Black Sea Sediments? PloS One 2014, 9, No. e101139.

(26) Egger, M.; Jilbert, T.; Behrends, T.; Rivard, C.; Slomp, C. P. Vivianite Is a Major Sink for Phosphorus in Methanogenic Coastal Surface Sediments. Geochim. Cosmochim. Acta 2015, 169, 217-235.

(27) Dijkstra, N.; Slomp, C. P.; Behrends, T. Vivianite Is a Key Sink for Phosphorus in Sediments of the Landsort Deep, an Intermittently Anoxic Deep Basin in the Baltic Sea. Chem. Geol. 2016, 438, 58-72.

(28) Cosmidis, J.; Benzerara, K.; Morin, G.; Busigny, V.; Lebeau, O.; Jézéquel, D.; Noël, V.; Dublet, G.; Othmane, G. Biomineralization of Iron-Phosphates in the Water Column of Lake Pavin (Massif Central, France). Geochim. Cosmochim. Acta 2014, 126, 78-96.

(29) Muehe, E. M.; Morin, G.; Scheer, L.; Pape, P. L.; Esteve, I.; Daus, B.; Kappler, A. Arsenic(V) Incorporation in Vivianite during Microbial Reduction of Arsenic(V)-Bearing Biogenic $\mathrm{Fe}(\mathrm{III})$ (Oxyhydr)Oxides. Environ. Sci. Technol. 2016, 50, 2281-2291.

(30) Thinnappan, V.; Merrifield, C. M.; Islam, F. S.; Polya, D. A.; Wincott, P.; Wogelius, R. A. A Combined Experimental Study of Vivianite and As (V) Reactivity in the PH Range 2-11. Appl. Geochem. 2008, 23, 3187-3204.

(31) Veeramani, H.; Alessi, D. S.; Suvorova, E. I.; Lezama-Pacheco, J. S.; Stubbs, J. E.; Sharp, J. O.; Dippon, U.; Kappler, A.; Bargar, J. R.; Bernier-Latmani, R. Products of Abiotic U(VI) Reduction by Biogenic Magnetite and Vivianite. Geochim. Cosmochim. Acta 2011, 75, 25122528.

(32) Taylor, K. G.; Hudson-Edwards, K. A.; Bennett, A. J.; Vishnyakov, V. Early Diagenetic Vivianite [Fe3(PO4)2.8H2O] in a Contaminated Freshwater Sediment and Insights into Zinc Uptake: A $\mu$-EXAFS, $\mu$-XANES and Raman Study. Appl. Geochem. 2008, 23, $1623-1633$.

(33) Liu, R.; Zhao, D. In Situ Immobilization of $\mathrm{Cu}$ (II) in Soils Using a New Class of Iron Phosphate Nanoparticles. Chemosphere 2007, 68, 1867-1876.

(34) Zachara, J. M.; Fredrickson, J. K.; Smith, S. C.; Gassman, P. L. Solubilization of Fe(III) Oxide-Bound Trace Metals by a Dissimilatory Fe(III) Reducing Bacterium. Geochim. Cosmochim. Acta 2001, 65, 75-93.

(35) Bae, S.; Sihn, Y.; Kyung, D.; Yoon, S.; Eom, T.; Kaplan, U.; Kim, H.; Schäfer, T.; Han, S.; Lee, W. Molecular Identification of $\mathrm{Cr}(\mathrm{VI})$ Removal Mechanism on Vivianite Surface. Environ. Sci. Technol. 2018, 52, 10647-10656.

(36) Madsen, H. E. L.; Hansen, H. C. B. Kinetics of Crystal Growth of Vivianite, $\mathrm{Fe} 3(\mathrm{PO} 4) 2 \cdot 8 \mathrm{H} 2 \mathrm{O}$, from Solution at 25,35 and $45^{\circ} \mathrm{C}$. J. Cryst. Growth 2014, 401, 82-86.

(37) Viollier, E.; Inglett, P. W.; Hunter, K.; Roychoudhury, A. N.; Van Cappellen, P. The Ferrozine Method Revisited: Fe(II)/Fe(III) Determination in Natural Waters. Appl. Geochem. 2000, 15, 785-790.

(38) Monperrus, M.; Tessier, E.; Veschambre, S.; Amouroux, D.; Donard, O. Simultaneous Speciation of Mercury and Butyltin Compounds in Natural Waters and Snow by Propylation and Species-Specific Isotope Dilution Mass Spectrometry Analysis. Anal. Bioanal. Chem. 2005, 381, 854-862.

(39) Etique, M.; Jorand, F. P. A.; Ruby, C. Magnetite as a Precursor for Green Rust through the Hydrogenotrophic Activity of the Iron- 
Reducing Bacteria Shewanella Putrefaciens. Geobiology 2016, 14, 237-254.

(40) Sameshima, T.; Henderson, G. S.; Black, P. M.; Rodgers, K. A. $\mathrm{X}$-Ray Diffraction Studies of Vivianite, Metavivianite, and Barićite. Mineral. Mag. 1985, 49, 81-85.

(41) Chukanov, N. V.; Scholz, R.; Aksenov, S. M.; Rastsvetaeva, R. K.; Pekov, I. V.; Belakovskiy, D. I.; Krambrock, K.; Paniago, R. M.; Righi, A.; Martins, R. F.; Belotti, F. M.; Bermanec, V. Metavivianite, $\mathrm{Fe} 2+\mathrm{Fe} 3+2(\mathrm{PO} 4) 2(\mathrm{OH}) 2 \cdot 6 \mathrm{H} 2 \mathrm{O}$ : New Data and Formula Revision. Mineral. Mag. 2012, 76, 725-741.

(42) Luna-Zaragoza, D.; Romero-Guzmán, E. T.; Reyes-Gutiérrez, L. R. Surface and Physicochemical Characterization of Phosphates Vivianite, Fe2(PO4)3 and Hydroxyapatite, Ca5(PO4)3OH. J. Miner. Mater. Char. Eng. 2009, 08, 591-609.

(43) Dyar, M. D.; Jawin, E. R.; Breves, E.; Marchand, G.; Nelms, M.; Lane, M. D.; Mertzman, S. A.; Bish, D. L.; Bishop, J. L. Mössbauer Parameters of Iron in Phosphate Minerals: Implications for Interpretation of Martian Data. Am. Mineral. 2014, 99, 914-942.

(44) McCammon, C. A.; Burns, R. G. The Oxidation Mechanism of Vivianite as Studies by Möessbauer Spectroscopy. Am. Mineral. 1980, 65, 361-366.

(45) Fejdi, P.; Poullen, J.-F.; Gasperin, M. Affinement de la structure de la vivianite $\mathrm{Fe} 3(\mathrm{PO} 4) 2 \bullet 8 \mathrm{H} 2 \mathrm{O}$. Bone Miner. 1980, 103, 135-138.

(46) Miot, J.; Benzerara, K.; Morin, G.; Bernard, S.; Beyssac, O.; Larquet, E.; Kappler, A.; Guyot, F. Transformation of Vivianite by Anaerobic Nitrate-Reducing Iron-Oxidizing Bacteria. Geobiology 2009, 7, 373-384.

(47) Miot, J.; Benzerara, K.; Morin, G.; Kappler, A.; Bernard, S.; Obst, M.; Férard, C.; Skouri-Panet, F.; Guigner, J.-M.; Posth, N.; Galvez, M.; Brown, G. E.; Guyot, F. Iron Biomineralization by Anaerobic Neutrophilic Iron-Oxidizing Bacteria. Geochim. Cosmochim. Acta 2009, 73, 696-711.

(48) Bouffard, A.; Amyot, M. Importance of Elemental Mercury in Lake Sediments. Chemosphere 2009, 74, 1098-1103.

(49) Figueiredo, M. O.; Silva, T. P.; Veiga, J. P. The Blue of Iron in Mineral Pigments: A Fe K-Edge XANES Study of Vivianite. Appl. Phys. A 2010, 99, 357-361.

(50) Rouzies, D.; Millet, J. M. M. Mössbauer Study of Synthetic Oxidized Vivianite at Room Temperature. Hyperfine Interact. 1993, 77, 19-28.

(51) Jorand, F.; Zegeye, A.; Landry, F.; Ruby, C. Reduction of Ferric Green Rust by Shewanella Putrefaciens. Lett. Appl. Microbiol. 2007, 45, 515-521.

(52) Byrne, J. M.; Klueglein, N.; Pearce, C.; Rosso, K. M.; Appel, E.; Kappler, A. Redox Cycling of $\mathrm{Fe}(\mathrm{II})$ and $\mathrm{Fe}(\mathrm{III})$ in Magnetite by $\mathrm{Fe}$ Metabolizing Bacteria. Science 2015, 347, 1473-1476.

(53) Pinto, H. P.; Michalkova, A.; Leszczynski, J. First-Principles Studies of Paramagnetic Vivianite Fe3(PO4)2.8H2O Surfaces. J. Phys. Chem. C 2014, 118, 6110-6121.

(54) Etique, M.; Zegeye, A.; Grégoire, B.; Carteret, C.; Ruby, C. Nitrate Reduction by Mixed Iron(II-III) Hydroxycarbonate Green Rust in the Presence of Phosphate Anions: The Key Parameters Influencing the Ammonium Selectivity. Water Res. 2014, 62, 29-39.

(55) Perez, J. P. H.; Freeman, H. M.; Schuessler, J. A.; Benning, L. G. The Interfacial Reactivity of Arsenic Species with Green Rust Sulfate (GRSO4). Sci. Total Environ. 2019, 648, 1161-1170.

(56) Yang, Z.; Fang, W.; Lu, X.; Sheng, G.-P.; Graham, D. E.; Liang, L.; Wullschleger, S. D.; Gu, B. Warming Increases Methylmercury Production in an Arctic Soil. Environ. Pollut. 2016, 214, 504-509.

(57) Osterwalder, S.; Bishop, K.; Alewell, C.; Fritsche, J.; Laudon, H.; Åkerblom, S.; Nilsson, M. B. Mercury Evasion from a Boreal Peatland Shortens the Timeline for Recovery from Legacy Pollution. Sci. Rep. 2017, 7, 16022.

(58) Herndon, E.; AlBashaireh, A.; Singer, D.; Roy Chowdhury, T.; $\mathrm{Gu}$, B.; Graham, D. Influence of Iron Redox Cycling on OrganoMineral Associations in Arctic Tundra Soil. Geochim. Cosmochim. Acta 2017, 207, 210-231.
(59) Gray, J. E.; Hines, M. E. Biogeochemical Mercury Methylation Influenced by Reservoir Eutrophication, Salmon Falls Creek Reservoir, Idaho, USA. Chem. Geol. 2009, 258, 157-167.

(60) Bravo, A.; Bouchet, S.; Tolu, J.; Björn, E.; Bertillson, S. Molecular Composition of Organic Matter Controls Methylmercury Formation in Boreal Lakes. Nat. Commun. 2017, 8, 14255.

(61) Lei, P.; Nunes, L. M.; Liu, Y.-R.; Zhong, H.; Pan, K. Mechanisms of Algal Biomass Input Enhanced Microbial $\mathrm{Hg}$ Methylation in Lake Sediments. Environ. Int. 2019, 126, 279-288.

(62) Bravo, A. G.; Bouchet, S.; Guédron, S.; Amouroux, D.; Dominik, J.; Zopfi, J. High Methylmercury Production under Ferruginous Conditions in Sediments Impacted by Sewage Treatment Plant Discharges. Water Res. 2015, 80, 245-255.

(63) Yu, R.-Q.; Flanders, J. R.; Mack, E. E.; Turner, R.; Mirza, M. B.; Barkay, T. Contribution of Coexisting Sulfate and Iron Reducing Bacteria to Methylmercury Production in Freshwater River Sediments. Environ. Sci. Technol. 2012, 46, 2684-2691.

(64) Xu, J.; Buck, M.; Eklöf, K.; Ahmed, O. O.; Schaefer, J. K.; Bishop, K.; Skyllberg, U.; Björn, E.; Bertilsson, S.; Bravo, A. G. Mercury Methylating Microbial Communities of Boreal Forest Soils. Sci. Rep. 2019, 9, 518.

(65) Kerin, E. J.; Gilmour, C. C.; Roden, E.; Suzuki, M. T.; Coates, J. D.; Mason, R. P. Mercury Methylation by Dissimilatory IronReducing Bacteria. Appl. Environ. Microbiol. 2006, 72, 7919-7921.

(66) Fleming, E. J.; Mack, E. E.; Green, P. G.; Nelson, D. C. Mercury Methylation from Unexpected Sources: Molybdate-Inhibited Freshwater Sediments and an Iron-Reducing Bacterium. Appl. Environ. Microbiol. 2006, 72, 457-464.

(67) Si, Y.; Zou, Y.; Liu, X.; Si, X.; Mao, J. Mercury Methylation Coupled to Iron Reduction by Dissimilatory Iron-Reducing Bacteria. Chemosphere 2015, 122, 206-212. 